\title{
THE REFORM OF THE LAW OF SALES
}

\author{
K. C. T. SUTTON
}

This article is the concluding portion to that found at (1969) 7 Alta. L.Rev. 130.

\section{III}

The foregoing suggestions for reform with their emphasis on provisions as to quality have, it is submitted, a particular significance for the consumer of goods, who is in a particularly vulnerable position as a largely unorganized David facing the Goliath of big business with its manufacturers' and retailers' associations, and its standard terms for doing trade. Further reforms which could assist the transition of the law of sales from the philosophy of the nineteenth century to that of the twentieth century age of technology are the abandonment of the emphasis on property in favour of the contractual aspects of the concept of sale, and the modernizing of the remedies available to the parties on breach. In this respect the changes wrought by the U.C.C. in its Article 2 dealing with the law of sales deserve careful study.

It is no exaggeration to say that the most fundamental change to be found in the Code is the shift in emphasis from the proprietary concept to the contractual aspects of the transaction of sale. The stage is set for this by the comment to s. 2-101, the introductory section to Article 2, where it is stated that:

The arrangement of the present Article is in terms of contract for sale and the various steps of its performance. The legal consequences are stated as following directly from the contract and action taken under it without resorting to the idea of when property or title passed or was to pass as being the determining factor. The purpose is to avoid making practical issues between practical men turn upon the location of an intangible something, the passing of which no man can prove by evidence and to substitute for such abstractions proof of words and actions of a tangible character...3

In other words, the passage of title as the basic test for deciding the rights and liabilities of the parties is done away with, and in its place arises the "specific problem" approach with different rules applying in different situations. Hawkland has put the matter succinctly when he says:

The U.C.C. abandons 'lump concept thinking' in favour of 'narrow-issue thinking' ... Consequently, the 'title' concept is relatively unimportant under the U.C.C. Under the U.C.C. the lawyer's search does not start with location of title. Rather his search should start with an analysis of the problem in terms of narrow issues, and an ascertainment of whether or not the U.C.C. contains specific provisions dealing with those issues. If it does contain specific provisions dealing with those issues the search ends at that point; if it does not contain specific provisions dealing with those issues, the 'title' concept must be employed. And, to this extent, the 'title' concept is still important."t

The Code abandons the technique of resolving nearly every question in the law of sales by reference to title and instead isolates various types of transactions or issues and deals with them under specific rules, bringing in the concept of title as a last resort to meet the situation not provided for. Under the S.G.A. the criterion for the transfer of rights is

*is The Uniform Commercial Code, 1 Uniform Laws Annotated 53 (1962). Cf. the words of Learned Hand. J., in In re Lake's Laundry Inc. (1935), 79 F. 2d. 326. 328-9 that "title is a formal word for a purely conceptual notion: I do not know what it mcans and I question whether anybody docs. except perhaps legal historlans."

s4 Sales and Bulk Sales 91 (1963). See too the preamble to s. $2-401$ to the effect that the provisions of Article 2 as to the rights of the partles apply irrespective of title. except where expressly otherwise stated. 
the passing of property, and the passage of title is made to depend on the presumed intention of the parties as ascertained in accordance with the rules set out in s. 23. If the parties manifest a definite intention, effect will be given to this, but in the absence of such a clear expression of intention resort must be had to the arbitrary rules of $\mathbf{s . 2 3}$.

Under the U.C.C., the seller's interest in the goods is conceived of as a bundle of rights which can be passed to the buyer at different times, and rules are laid down to determine when those rights are transferred. Some rights may exist in both parties at the same time, as for instance the right to insure and the right to sue third parties for damage done to the goods. The Code will give effect to an explicitly stated intention by the parties-for example the provisions as to risk of loss in s. 2-509 are made subject to the contrary agreement of the parties-but in the absence of this it will resort to the "specific problem" approach. This is of course as arbitrary as the "presumed intention" test, but it at least has the merit that it looks to a specific situation and the relative positions of the parties in that situation, and hence is more in accord with commercial practice and common-sense.

An analysis of the rules relating to the incidence of the risk of loss will make the position under the Code clearer. The nineteenth century concept of an arbitrary shifting of the risk as property passed in the goods, is done away with, and instead delivery or tender of delivery is recognized as he controlling factor. Section 2-509 divides the sales contract into two broad categories depending on whether the seller has to ship the goods by carrier or not. If it is a shipment contract the risk passes on shipment (even though the seller retains a security interest) where the seller is not required to deliver at a particular destination, or on tender of delivery where he is so required. If it is not a shipment contract, risk passes to the buyer on his receipt of the goods where the seller is a merchant, and on tender of delivery in other cases. ${ }^{85}$ The rationale for this distinction is that a merchant who is to make physical delivery at his own place can be expected to insure them in the meantime.

These rules are subject to the contrary agreement of the parties and to the provisions of s. 2-510 dealing with the effect of breach of contract on the incidence of risk of loss. Under this section the risk is on the seller where he has broken the contract by tendering non-conforming goods, thus entitling the buyer to reject. The section then makes a novel attempt to bring into account in assessing liability for loss the insurance cover held by the innocent possessor of the goods. A buyer who rightfully revokes acceptance (of which more anon) may treat the risk of loss as on the seller to the extent of any deficiency in the buyer's effective insurance cover; while an innocent seller is permitted to treat the risk of loss as on the buyer to the same extent, where the buyer is in breach before the risk has passed to him. In effect, the risk is placed on the innocent party to the extent that he has insurance i.e. the insured loss falls on the innocent party's insurance company while the uninsured loss falls on the party in breach; and as the section deals with the allocation of risk and not with the transfer of the proceeds of 
any insurance, the insurer has no right of subrogation against the guilty party.

This provision seems to be a clear acceptance of the theory of distribution of risk, the only justification for allowing the guilty party to take advantage of the innocent party's insurance being the desirability of having the commercial community as a whole bear the losses occurring at random within that community. The effectiveness of the provision will of course depend on whether the innocent party has insured or not, and the whole premise on which the provision is based appears to be that only parties who are in possession of the goods will be likely to insure.

From what has been said it will be seen that the approach adopted by the U.C.C. to the question of incidence of risk is quite different to that of the S.G.A. but that in some cases at least the ultimate result will be the same. In other cases however the result under the Code is markedly at variance to that under the S.G.A. Thus, under s. 24 (1) of the Act, the reservation of the right of disposal by the seller prevents property in the goods and therefore risk of loss from passing, notwithstanding delivery to a carrier for dispatch to the buyer, but under the Code the reservation of a security interest does not prevent the risk from passing. ${ }^{80}$ Again, where a person unconditionally sells a specific motor vehicle in a deliverable state, the property (and risk) will pass to the buyer under s. 23 r.1 of the S.G.A. at the time the contract is made, unless a different intention appears. But under s.2-509(3) of the U.C.C. the risk of loss will pass to the buyer on his receipt of the goods if the seller is a merchant (the seller is more apt to carry insurance until the goods are out of his hands in this event), or on tender of delivery if he is not. Protection is afforded the seller against the defaulting buyer by s. 2-510 (3) whereby the risk is on the buyer to the extent of the deficiency in the seller's insurance cover-at least until the elapse of a reasonable time, when the seller should again be expected to take the full risk.

Other problems decided under the S.G.A. either directly or indirectly in relation to the passage of title but now dealt with specifically in the Code, include the point of time at which the buyer obtains an insurable interest in the goods, the buyer's right to the goods on the seller's insolvency, his right to replevy the goods, and the seller's right to sue for the price. Precise rules as to when an insurable interest arises are contained in s. 2-501, but these rules are declared not to derogate from other rules of law on the subject. Briefly put, the seller retains an insurable interest so long as title to or any security interest in the goods remains in him, while the buyer has an insurable interest and also a special property in the goods when they are identified i.e. when the goods are designated by one or both parties as those to which the contract refers. ${ }^{87}$

This identification of the goods giving the buyer a special property in them, is an essential element in the creation of a novel remedy under the Code whereby the purchaser who has paid part or all of the price

kit S. 2-509(1). Cf. s. $20(2)$ U.S.A. S. 2-509(1) is consistent with the provisions of the U.S.A.- see 8. 19 r. 5 and s. $22(\mathrm{a})$.

8; "Identification" is not just another word for the "appropriation" of the S.G.A.. for while title to goods cannot pass prior to identification, the U.C.C. does not say that title must pass once the goods are identified. Whether title passes or not depends on the rules set out in $\mathbf{s}$. $2-401$. 
can recover the goods from the seller if he becomes insolvent within ten days after receiving the first instalment of the price." In effect, the buyer is given specific performance of the contract so that he may have the fruits of his bargain. He has of course to tender any unpaid portion of the price. The position is in marked contrast to that under the S.G.A. where the buyer's right on the seller's insolvency to demand delivery of the goods after tender of the price depends on location of title. If property has not passed, the buyer's only remedy is a claim for damages against the seller's estate. Under the U.C.C. location of title is unimportant, the vital factors being advance payment and identification, followed by the seller's insolvency within the required ten days. ${ }^{80}$

The theoretical basis for this novel provision appears to rest on the notion of "implied fraud", the argument being that the seller must know of his impending bankruptcy at the time the sale is made, if he actually becomes insolvent within the succeeding ten days. The section has been attacked however on the ground that the buyer's right of recovery constitutes a voidable preference under the Bankruptcy Act, but it would seem that if there is no intention on the part of the buyer to grant the seller credit and that the aim is to make payment of the price and delivery of the goods roughly contemporaneous, the buyer's recovery of the goods cannot be impeached."0 Some attempt to meet the position is made by s. 2-402(1) of the Code which makes the rights of unsecured creditors of the seller subject to the buyer's rights of recovery. The only exception is where retention of possession of the goods by the seller after sale may be regarded as fraudulent vis-á-vis one of the seller's creditors, but even this exception is qualified by the provision that retention of possession "in good faith and current course of trade by a merchant-seller for a commercially reasonable time after a sale" is not fraudulent. This qualification would seem to cover most situations coming within the purview of s. 2-502, for retention for a period up to ten days will usually be for a commercially reasonable time and the reasons for retention will generally be in the current course of trade. ${ }^{21}$ The terms are not defined and are quite vague.

The counterpart of this right of the buyer to recover is the right given to the seller to reclaim his goods on discovery of the buyer's insolvency. Under s. 2-702 a seller who discovers that the buyer has received goods on credit while insolvent, may reclaim them on making demand within ten days after receipt. The reclamation period is not restricted to ten days if a written misrepresentation of solvency (whether innocent or fraudulent) has been made to the seller within three months before delivery. "' This provision is a major departure from the present law under which an unpaid seller loses his rights over the goods when he delivers them to the buyer on credit, but nevertheless the seller is

48 See 8. 2-502.

89 Quaere the position if the seller is insolvent when the first payment is made to him. The scction would seem to require insolvency to occur subsequently to the initiai payment.

g0 1 Hawkland. Transactional Guide to the U.C.C. 257 (1964) suggests that the voidable preference provisions of the Bankruptcy Act are never a barrier to one reclaiming goods on the ground of fraud, and that 5 . 2-502 presumes fraud in a situation in whlch the buyer almost surcly could prove it.

o1 Quaere the position if the seller's trustee in bankruptcy elected not to adopt the contract of sale on the ground that it was unfavourable. The contract would still be executory so far as the seller was concerned.

92 A seller might attempt to take advantage of this provision by inserting a clause in a written contract of sale whereby the buyer declares himself to be solvent. 
permitted to rescind the contract and recover his goods (if they have not passed into the hands of third parties or some other bar to rescission is operative) provided he can prove that delivery was induced by a fraudulent misrepresentation of solvency or intention to pay. Under the Code provision, fraud need not be shown, the only requirements being insolvency and demand for return of the goods within ten days of receipt. The rationale again seems to be that receipt of the goods on credit by an insolvent buyer amounts to a tacit business misrepresentation of solvency and is therefore fraudulent.93

Section 2-702 goes on to provide that the seller's sole remedy to recover goods on the ground of a fraudulent or innocent misrepresentation of insolvency or intent to pay"1 is that set out in the section, that successful reclamation bars the seller from asserting any other remedy against the buyer with respect to the goods (since it constitutes a preference in favour of the seller as against the buyer's other creditors), and that the right to reclaim is subject to the rights of a "buyer in ordinary course" or other good faith purchaser.

So far as the seller's other remedies on discovery of the buyer's insolvency are concerned, the U.C.C. does not depart markedly from the S.G.A. The right to refuse delivery except for cash including payment for all goods already delivered, even though he may have agreed to extend credit, is simlar to s. 43 (1) (c) S.G.A. and is but a specialized application of the broad contractual principle that a party need not perform his side of the bargain when the agreed performance of the other party will not be tendered. ${ }^{.3}$ The right of stoppage in transitu has its counterpart in s.46 of the S.G.A. but the Code provision is broader in scope in that the right is not limited to the insolvency of the buyer but extends to large shipments in other situations, ${ }^{96}$ any bailee holding the goods is included, and the circumstances in which the right comes to an end and the resultant obligations are more clearly spelt out.07

The seller's right to sue for the price, with one exception ${ }^{0 \times}$ depends under the S.G.A. upon whether or not the property in the goods had passed to the buyer. This requirement is done away with in the U.C.C., and the price is recoverable where the goods have been accepted, or where they have been lost or damaged after the risk has passed to the buyer, or where the seller is unable, after reasonable efforts in that behalf, to resell the goods at a reasonable price. ${ }^{90}$ The seller is made responsible for holding the goods on behalf of the buyer, since an action for the price in effect forces the buyer to take the goods, but the U.C.C. does allow the seller to re-sell the goods and credit the buyer with the proceeds if re-sale becomes possible.

Where the seller cannot succeed in an action for the price, he is entitled to damages for non-acceptance based on the difference between the market price at the time and place for tender and the contract price. ${ }^{100}$

is See comment 2 to s. 2-702.

94 It will be noted that recovery for misrepresentation of other facts is not excludcd.

os Sce Beale v. Huggins \& Fintey. [1918] S.A.L.R. 15, 38-44.

an The exclusion of small shipments is to avoid imposing an cxcessive burden on the carrier. The risht of stoppase is probably not as imporiant as it once was in view of the areatly increased use of the letter of credit in overseas trade.

o: See s. 2-705. The term "seller" is extended by s. 2-707 beyond the definition contained in S. 41 (2) S.G.A. to include a financing agency with a sccurity interest in the goods.

ux Where the price was payable on a day certain irrespective of delivery.

ต9 S. 2-709.

100 S. 2-708. Under s. 2-724 market quotations are admissible as evidence of market price. 
If evidence of the market price is not readily available, proof of a substitute market may be given in accordance with the terms of s. 2-723(2). This carries forward the position under the S.G.A. with little change except that the time and place for measuring damages are explicitly set out, ${ }^{101}$ the recovery of incidental damages as defined in s. 2-710 is expressly authorized, ${ }^{102}$ and the circumstances in which the recovery of lost profits will be allowed is made clear. The Code provides in s. 2708 (2) that if the measure of damages based on market price is inadequate to put the seller in as good a position as performance would have done, then the measure of damages is the profit, including reasonable overhead, which the seller would have made from full performance by the buyer, together with incidental damages, with due credit for payments or proceeds of re-sale. This provision setting out the circumstances in which the market-price formula may be inadequate, is more flexible than the "available market" criterion of the S.G.A. with its attendant difficulties arising from the existence of standard prices and the state of supply and demand at the relevant time.

As an alternative to claiming damages based on the time-honoured market-price formula, the seller can re-sell the goods and claim as damages the difference in price together with the costs incurred. ${ }^{103}$ The re-sale must be made "in good faith and in a commercially reasonable manner"104 and the seller is in effect establishing his own market price as at the time of re-sale as a basis for claiming damages. So long as he has acted reasonably, the re-sale price as a basis for assessing damages cannot be called in question, no matter how widely it may differ from the current market price. This differs markedly from the S.G.A. where the market provides the basic test, although the seller's re-sale price is sometimes taken as evidence of that figure. The section goes on to provide that the seller is not accountable to the buyer for any profit made on a re-sale, thus avoiding the difficulties which have arisen under the S.G.A., as witness Gallagher v. Silcock. ${ }^{105}$

It must be confessed that, compared with its counterpart in $\mathbf{s . 5 0}$ of the S.G.A., the re-sale section of the Code is a model of clarity and precision. ${ }^{00}$ Further, it is wider than s. 50, for under the Act only an unpaid seller has a right of re-sale, while under s. 2-706 of the U.C.C. a seller can exercise this right if the buyer wrongfully rejects or fails to make a payment due (which includes dishonour of a cheque) or repudiates in whole or in part. Under the S.G.A. re-sale is primarily a device to enforce a lien, while under the Code the basic purpose of resale is to establish the quantum of damages.

Section 2-704 allows an aggrieved seller whose goods are in the process of manufacture to complete the process where it would be reasonably commercially sound to do so to avoid loss, and then to re-sell the goods; or he can cease manufacture and resell for scrap if such a course is reason-

107 Under s. 2-723(1) damages in an action based on anticlpatory repudiation may be determined according to the market price prevailing when the aggrieved party learnt of the repudiation. See too s. $2-713$.

102 In any event these incidental damages would probably come within the scope of the formula in Hadley v. Baxendale (1854), 23 L.J. Ex. 179.

$1035,2-706$.

104 The term "commercially reasonable" is not defined, but it is suggested that it embraces the accepted commercial practices of the community and what a fair-minded merchant would do in the light of these practices in the particular circumstances of the case.

105 [1949] 2 K.B. 765. But see now Ward v. Bignall, [1967] 1 Q.B. 534.

100 The difficulties of construing the section are illustrated by Ward v. Bignall, ibid. 
able. The fact that his conduct must be judged in the light of what is commercially reasonable, and the practical difficulties surrounding the recovery of damages from a defaulting buyer, should be a sufficient safeguard against wasteful action by the seller in exercising the powers conferred on him by this provision. There is no corresponding provision in the S.G.A., but a similar rule might be spelt out of the common law principle requiring an injured party to take reasonable steps to mitigate his loss consequent on breach. So far as expending money on goods in order to render them fit for re-sale is concerned, it would seem that at common law the question is one of reasonableness depending on the nature of the goods, the market for them, and the costs involved. ${ }^{107}$ However, an express provision sanctioning completion where it is reasonable, is infinitely to be preferred.

The basic policy of the U.C.C. seems to be to avoid economic wastethe same notion which underlies the principle of the mitigation of damage-and to encourage re-sale of goods by the aggrieved seller, or actual substitute purchase (or "cover") by the injured buyer, thus using the market price as a measure of damages. The seller who has made improper tender or delivery may in certain circumstances correct (or "cure") the defective tender, while either party who has reasonable grounds for insecurity with respect to the performance of the other side, may demand adequate assurance of due performance and suspend his own performance until this is forthcoming. Failure to provide adequate assurance of performance is a repudiation of the contract. ${ }^{108}$

The seller's right to "cure" or correct a defective tender is an interesting innovation and will be considered here although it is not a remedy available to an innocent seller as against a defaulting buyer.

The Code seeks to mitigate the general rule enshrined in $5.2-601$, which gives a buyer power to reject the whole if the goods fail in any respect, ${ }^{100}$ by giving the seller a second chance to comply with the contract where he has initially tendered non-conforming goods. If the seller can do so within the original contract period he is permitted by s. 2-508 to notify the buyer of his intention to "cure" and may then make a proper delivery within the time specified for performance. Further, if the seller is taken by surprise by the rejection of a non-conforming tender which he had reasonable grounds to believe would be acceptable (the sort of manoeuvre which an unscrupulous buyer would adopt to escape a bargain made unfavourable by a falling market), he can notify the buyer and have a reasonable time (not necessarily limited to the time specified in the contract) within which to "cure" his defective delivery. But while this right may be of some assistance to the seller, the economics of the situation will prevent it being of much help to a distant seller on a falling market-the very time when rejection by the buyer on flimsy or technical grounds is most likely.

If attention is now paid to the remedies available to the buyer, it will be seen that they fall into three categories (a) a combination of the recovery of money paid and revocation of acceptance with damages for non-delivery; (b) the award of damages based on substitute purchase or "cover" as an alternative to damages based on market-price; and (c)

10i See Hammer \& Barrow v. Coca-Cola, 11962| N.Z.L.R. 723. 735.

$10 \mathrm{R}$ S. 2-609.

109 Other limitations of the buyer's right to reject are contained in s. 2-612 and s. 2-614 dealing with instalment contracts and a frustration situation respectively. See infra. 
the expansion of specific performance beyond its application to "unique" goods, together with a right of replevin in certain circumstances.

The buyer is given the right to reject the goods for any failure to conform to the contract, and is not limited to cases of material breach of contract by the seller. This right of rejection is of vital importance, as it throws on to the seller the burden of disposing of the goods-a difficult task in the case of a falling market. Under the S.G.A. the right of the buyer to reject is hedged about with technicality and uncertainty. So far as specific goods are concerned, the right is lost when property has passed (which is frequently at the time the contract is made) ${ }^{110}$ although there is some authority that specific goods are to be equated with unascertained goods in this respect and rejection allowed up to the time of acceptance. ${ }^{111}$ Legislation in England has now achieved this result with the provision in s. 4(1) Misrepresentation Act 1967 deleting the separate rule for specific goods in the S.G.A. and thus making acceptance the sole criterion.

As indicated earlier, Williston in drafting the U.S.A. abandoned the English pattern of distinguishing between conditions and warranties as a basis for rescission, and sought simplicity and predictability by allowing a buyer to refuse to accept the goods if property had not passed, or to rescind the contract for any breach of warranty, using that term in a wide sense to cover the entire scope of the seller's obligations in relation to the goods.1" At the same time, safeguards against allowing a buyer to rescind for a trivial breach were provided by stipulating that to be a warranty the natural tendency of any affirmation must be to induce the purchase and the buyer must actually rely thereon, i.e. it must be material. ${ }^{13:}$ The passing of property or the technical acceptance of the goods did not affect the remedy of rescission.

The U.C.C. has continued the U.S.A. rule and indeed seems to go beyond it by allowing a buyer to reject "if the goods or the tender of delivery fail in any respect to conform to the contract," but proceeds to limit this rule in various ways. Thus, there is the seller's ability to "cure" which has already been considered. Further, in an instalment contract an instalment can only be rejected if the non-conformity "substantially impairs" the value of that instalment; ${ }^{111}$ and thirdly, where in any contract the agreed manner of delivery becomes commercially impracticable, a commercially reasonable substitute, if available, must be tendered and accepted. "1". The Code recognizes also that the buyer may agree to limit his right to reject, and so long as such contractual limitation is not unconscionable, it will be given effect to. Clauses like this would presumably not be unconscionable in contracts between merchants where an adjustment of the price would achieve substantial justice in the normal case, but such a clause might well be objectionable where the goods have been bought by a consumer for use and not for re-sale.

The rule is further restricted by the provision that failure to make effective rejection constitutes acceptance, thus precluding rejection, and that revocation of acceptance is permitted only in very limited circum-

111 S. 16(3) and s. 23 r.1 S.G.A.

111 Sec the discussion in Sutton, oll. cit. sumra, n. 20, at 153-8.

$11:$ Sec Honnold. Buyer's Right of Rejection (1949), 97 Univ. Pa. L.R. 457, 460.

11: Ss. 12, 69(1) U.S.A. The right to rescind was lost by failure to notify the seller within a reasonable time or to return the goods in the same condition-see s. $69(3)$.

114 S. $2-612(2)$

11 S. 2-614(1): See too s. 2-504. 
stances and then only if the defects "substantially impair" the value of the goods to the buyer. The buyer must have accepted the goods on the assumption that the defects would be cured, or if he was not aware of the non-conformity, his acceptance must have been induced either by the difficulty of discovery before acceptance or by the seller's assurances. ${ }^{13 \prime}$ But it is to be noted that no implication of acceptance flows from the buyer's possession of the goods until he has had a reasonable opportunity to inspect them. ${ }^{11 i}$

It is not suggested that any reform of the buyer's right of rejection in the S.G.A. should go the whole way that the U.C.C. has gone, but it is suggested that what is needed in the Act is a clear statement of when the buyer's right to reject arises, how this right is to be exercised, whether partial rejection is to be allowed or not and the rights and duties of the buyer in respect of the goods on rejection. ${ }^{115}$ At the same time the law as to what constitutes acceptance should be clarified and the English precedent followed, so that s. 37 of the S.G.A. prevails over s. 38 and there can be no acceptance unless there has first been a reasonable opportunity to examine the goods. ${ }^{119}$ A buyer should only be permitted to reject where the breach is material, as both the S.G.A. and the U.S.A. recognized, (although there was lack of agreement on what constituted materiality), and it is suggested that acceptance of the goods should be the point at which the right to reject is lost. But acceptance should be carefully defined so that it can only arise after a reasonable opportunity to inspect the goods has been afforded the buyer irrespective of whether he has re-sold the goods or not. This would involve a clarification of the current thinking as to what constitutes an "act inconsistent with the ownership of the seller" within the meaning of s. 38 S.G.A.'?"

As in the S.G.A. the remedies available to the buyer under the U.C.C. depend largely upon whether he has accepted the goods or not. Acceptance precludes rejection and the buyer must pay "at the contract rate" for any goods accepted but may claim damages for any loss suffered. ${ }^{191}$ But where there has not been acceptance, as for instance where the goods are not delivered by the seller or are rightfully rejected by the buyer, or acceptance is revoked, the remedies available include (a) rescission and recovery of any payments made on account of the price together with damages for non-delivery; (b) the right to "cover" and obtain damages; and (c) in appropriate circumstances the right to demand specific performance or replevin of the goods. Two matters only will be investigated here, the buyer's right to "cover" and the extension of the remedies of specific performance and replevin.

The right to "cover" which is purely optional permits the buyer to go into the open market to procure substitute (i.e. not necessarily identical) goods to meet his needs, and the measure of his damages will be related

110 Ss, 2-606(1) (b), 2-607 (2), and 2-608.

11i S. 2-606(1) (b). The same result would seem to obtain in England since the enactment of s. 4(2) Misrepresentation Act 1967 whereby s. 37 becomes the dominant section nver s. 38 S.G.A.

119 The U.C.C. sets out the buyer's duties in respect of the gonds which vary according to whether the buyer is a merchant or not. The buyer is also declared to have a security interest in the soods for any payments made on their price and any cxpenses reasonably incurred and may re-sell the goods to recoup his outlay. See 85. 2-603, 8-604 and 2-711(3).

$11 !$ See supra. $n$. 117. This would mean the end of Hardy v. Hillerns \& Fowler, |1923| 2 K.B. 490 and Its progeny.

120 The dictum of Devlin. J.. in Kwei Tek Chao v. British Traders \& Shimers Ltd., [1954] 2 Q.B. 459 , 487 would repay careful study in any projected reform of this area of the S.G.A.

121 Ss. 2-607, 2-714, and 2-717. 
to the amount he actually spends, not the general market level. However, he must act reasonably, and the market-price has a bearing on this. It seems that the buyer has a right to "cover" immediately on the seller's repudiation of the contract even though it is in advance of the agreed date for performance. This is akin to the measure of damages set out in the Code where the buyer decides not to "cover" but to claim damages based on the market-price. In such an event, the damages are assessed by reference to the market-price at the time when the buyer learned of the breach." This prevents any speculation by the buyer on the wisdom of effecting "cover" as opposed to claiming damages based on the market-price.

If the buyer is unable to effect "cover" after reasonable efforts to do so, or if the circumstances indicate that any such effort will be unavailing, he has a right of replevin for goods identified to the contract. ${ }^{23}$ This is in addition to the buyer's right to recover identified goods on the seller's insolvency already considered. The right will accrue to the buyer only where the goods have been designated and substitute goods cannot be obtained on the market at a reasonable price, thereby making it appropriate that he should be able to acquire the very goods he has agreed to buy. It will be noted that the remedy does not depend on the property in the goods having passed to the buyer, and that the limitation of the right to the situation where "cover" is not reasonably possible, is reminiscent of the basis on which the remedy of specific performance is granted under the S.G.A. Under the U.C.C. a decree of specific performance may be made, and this is not limited to specific goods, but the goods must be "unique" or "other proper circumstances" must exist. The test of uniqueness is not defined, and the comment to the section gives some support to the view that what should be considered is the unavailability of substitutes, taking into account a peculiarly available source or market, and the extent to which monetary compensation would not be a really adequate remedy ( $a$ in the case of failure to deliver a motor-car in a time of shortage)..$^{124}$

\section{IV}

The foregoing analysis of some of the innovations introduced in the law of sales by Article 2 of the U.C.C. has been made so as to indicate the changes wrought in traditional concepts by this modern reformulation of commercial law. It is not suggested that every change should be slavishly copied in any revision of the S.G.A. in Australia, but the principles adopted by the framers of the Code should be carefully examined in the light of present-day conditions before any major re-casting of sales legislation is undertaken in this country. Where it is thought that these principles would better serve the community in this day and age than the rules enshrined in the S.G.A., they should be adopted. But the

122 The U.C.C. deals clearly with the time and place for ascertaining the market-price of the soods for the purposes of assessing damages, both in the case of anticipatory repudiation and otherwise. See ss. 2-708(1), 2-713, and 2-723(1). The S.G.A. needs clarification in this respect.

12is 5. 2-716(3). The right to replevy also arises if the goods have been shlpped under reservation, and satisfaction of the sccurity interest has been made or tendered.

1.. S. 2-716(1). Cf. Cook v. Rodgers (1946), 46 S.R. (N.S.W.) 229 where speclfic performance was refused in a similar situation. On the sale of a trucking business, the interstate commerce commission certificates were held to be unique within the meaning of s. 2-716(1) in McCormick Dray Line Inc. v. Lovell (1957), 13 D. \& C. 2d. (C.P. Pa.). Presumably such certificates are "goods." 
draftsmanship of the U.C.C. will need to be overhauled and the concepts contained therein re-written in familiar language away from the narrative style, the vague prose, and the explanatory comments of Article 2. What will be required will be to re-cast the principles of the U.C.C. in the terse, concise, and precise phraseology of the statute-book familiar to local lawyers. The price that will have to be paid for this particularization and precision will be an inevitable loss of flexibility to meet changing commercial conditions, as can be seen from the present state of the S.G.A. Amendment is a costly, cumbersome and tardy process, but it is suggested that it is preferable to the generalizations of codification.

Not every innovation contained in the U.C.C. has been referred to in the above survey of the provisions of Article 2, and mention could be made of many other changes that have been effected, to which attention must be paid in any overhaul of the S.G.A. To name but a few, there is the codification of the common law principles dealing with C.I.F. and F.O.B. contracts and their variants which provides detailed rules for the construction of these important trade terms and the obligations of the parties thereunder; ${ }^{12 i}$ there is an exposition of the rights and duties which arise on the creation of a letter of credit; ${ }^{130}$ there are detailed rules which perpetuate the distinction drawn in the U.S.A. between contracts of sale "on approval" and "sale or return" and clarify the legal incidents in respect of each classification;": there is a reformulation of the law as to impossibility of performance through the destruction of the goods or the failure of presupposed conditions, covering such eventualities as partial loss or substantial deterioration and the failure of the agreed manner of shipment or delivery or the medium of payment; ${ }^{128}$ and there is a recognition, stemming again from the provisions of the U.S.A., of the prominent part played by documents of title in modern commerce.

The S.G.A. is sadly lacking in its treatment of documents of title. In the modern world of commerce, the majority of transactions are carried out by the handing over of documents in respect of the goods rather than the goods themselves. Yet, apart from special statutory provisions, or proof of an established custom, the handing over of a delivery order or warrant is ineffective in the absence of attornment by the warehouseman or other bailee. The extent to which the S.G.A. has altered the common law position in this regard is a matter of considerable doubt. ${ }^{129}$ The U.S.A. departed radically from the position adopted by the S.G.A. by setting out detailed provisions in respect of documents of title. ${ }^{130}$ They were classified as either negotiable or non-negotiable documents, the distinction being whether or not the document stated that the goods were deliverable to bearer or to the order of a person named, in which case the document was negotiable either by delivery or by endorsement and delivery. All other documents were non-negotiable. Only delivery

125 See 8s. 2-319 to 2-324. The S.G.A. is concerned primarily with internal trade which nevertheless makes some use of trade terms, but the Act should be extended to cover export and import transactions as well. In this regard, some attention should be paid to the Uniform Laws on International Sales Act 1967 (U.K.) based on the Hague Convention of 1964 .

120 See Article 5 and s. 2-325.

127 See ss. 2-326 and 2-327. See too General Electric Co. v. Pettingell Supply Co. (1964), 199 N.E. 2d. 326 and Guardian Discount Co. v. Settles (1966), 151 S.E. 2d. 530.

128 Ss. 2-613 to 2-616. See Transatlantic Financing Corpn. v. U.S. (1966), 363 F. $2 d .312$.

329 See Sutton, op. cit. supra, n. 20, at 247-255.

130 See ss. $27-40$. 
of the goods to the holder of the negotiable document would discharge the liability of the person issuing the document, i.e. delivery was against surrender of the warrant, and it followed from this that title derived from the document prevailed over title derived from the goods. But if goods were shipped or warehoused under a non-negotiable document, the bailee could deliver the goods to the named consignee without requiring production of the warrant, and the transferee of the document received no favoured treatment.

The U.C.C. has maintained this distinction between the two types of documents of title but has dealt with the whole topic in expanded form in a separate Article.':1 Any overhaul of this area of the law of sales to bring the S.G.A. into line with commercial practice would require a study of the American treatment of the topic, and at the same time care would have to be taken to ensure that modern developments such as the growth of carriage of goods by air with the increased use of the air waybill and the acceptance of containerization as a method of transporting goods were not forgotten.

In this overlong paper, space will permit of reference to only one more topic, namely the reform of the rule nemo dat quod non habet and the exceptions to it. It will be recalled that the English Law Reform Committee issued a Report on this topic in April, 1966 in which they made a number of recommendations for the reform of the law, while upholding the basic rule that a person who does not own goods he purports to transfer cannot pass a good title to them. The soundness of this rule will be apparent, but in the writer's view it smacks a little too much of the preoccupation with the rights of property which was a feature of nineteenth century jurisprudence. The exceptions to it should be widened, as indeed the majority of the Law Reform Committee recognized. Personally, the writer cannot see why the much maligned dictum of Ashhurst, J., in Lickbarrow v. Mason":" that "wherever one of two innocent persons must suffer by the acts of a third, he who has enabled such third person to occasion the loss must sustain it" should not represent the law, and that any one whose negligence has enabled a rogue to defraud an innocent third party should bear the loss. In McRae v. Commonwealth Disposals Commission ${ }^{133}$ the High Court of Australia expressed the view that gross negligence on the part of the defendant precluded it from relying on any defence of common mistake, as any mistake that existed was induced by its own culpable conduct. Similarly, it can be argued that the owner of goods should not be entitled to rely on his right of property when his own negligence has induced his loss of possession.

But as the law now stands the precise limits of estoppel by negligence are difficult to state, and the requirements of a duty to the person misled and breach of that duty ${ }^{131}$ are a serious restriction on the operation of the doctrine, unless the view of Lord Denning is accepted viz. that the owner who hands over goods to a stranger intending to part with the property in them owes a duty to any person to whom the goods might

131 See Article 7, especially ss. 7-104 and 7-501-502. See too ss. 2-503(4) and 2-509(2).

132 (1787), 2 T.R. 63, 70; 100 E.R. 35.

133 (1950), 84 C.L.R. 377, 409, 410.

134 See Mercantile Bank of India Ltd. v. Central Bank of India Ltd., [1938] A.C. 287. 
be disposed. ${ }^{13:}$ How far the doctrine will assist in the present state of the law is a matter for conjecture.

If there is no negligence on the part of the owner, as happened for instance in the well-known case of Ingram v. Little, $1:$ i: then it seems only consonant with justice that the loss should be apportioned between the two innocent victims of the fraud of a third party, as indeed Devlin, L.J., suggested in that case. It is difficult to see why the English Law Reform Committee in its 1966 Report refused to countenance such a proposal. The stated grounds that uncertainty would result and that the practical and procedural difficulties involved would be considerable, hardly seem weighty enough to justify the rejection of the idea of apportionment. Adoption of this scheme would also have the effect of obviating the necessity for distinguishing between contracts void for mistake and those voidable for fraud, at least in the sphere of sale of goods. ${ }^{13:}$

The alternative is to adopt the solution put forward in the U.C.C. and to provide for the protection (at the expense of the owner) of the bona fide purchaser for value in a number of specific situations, including those where the transferor was deceived as to the identity of the purchaser and where the goods were delivered in exchange for a cheque which was later dishonoured. In such case, a bona fide third party purchaser obtains a good title. ${ }^{13 \times}$ This represents a basic change in policy away from the legalistic refinements of estoppel and the true intention of the seller who is mistaken as to the other party's identity, in favour of the bona fide purchaser for value from the rogue, ${ }^{1: 19}$ and, as such, can be justified on the ground that the owner of goods has a much better opportunity to verify the identity and worth of his potential customers than the third party purchaser, who generally has no ready means of ascertaining whether his vendor has a valid, voidable or void title. Of course, it may not be commercially feasible to check on the identity of every potential customer, in which case the Code's policy represents the practical view that a merchant may be prepared to accept the risk of occasional loss on the assumption that most buyers are honest.

In the commercial field, buyers are protected by the provision whereby any entrusting of possession of goods to a merchant who deals in goods of that kind gives him power to transfer all rights of the entruster to a buyer in the ordinary course of business. ${ }^{1.10}$ This is reminiscent of the Factors Act but it is wider in that entrusting is defined" "any delivery and any acquiescence in retention of possession regardless of any condition expressed between the parties to the delivery or acquiescence and regardless of whether the procurement of the entrusting or the possessor's disposition of the goods have been such as to be

18. See Central Newbury Car Auctions Ltd. v. Unity Finance Ltd.. |1957| 1 Q.B. 371, 385-6. See too Mercantile Credit Co. Ltd. v. Hamblin, |1965| 2 Q.B. 242.

134: 11961| 1 Q.B. 31 .

13: The U.K. Law Reform Committee in its Twclfth Rcport issued in 1966 on Transfer of Title to Chattels recommended that contracts at present void for mistake as to Identity should be treated as voidable so $\mathrm{fnr}$ as third party purchusers were concerned.

1:4 $\mathrm{S}$. 2-403(1). Where a rogue falsely claims to be the agent for an identified princlpal. as in Roache v. Australian Mercantile Land \& Finance Co. Ltd., |1964-5| N.S.W.R 1015. the deception is not as to the identity of the purchaser but as to the nuthority of the asent.

1:10 But apart from these specific situations, the common law doctrines of estoprcl and apparent ownership will still apply. S. $2-403$ (1) provides that a purchaser acquires all title which his transferor "had power to transfer."

3.40 S. $2-403(2)$

141 S. $2-403(3)$. 
larcenous under the criminal law." 12 In other words, the entrusting need not be merely for the purposes of sale, but would include entrusting for the purpose of obtaining offers to buy, or for storage, or even, it would appear, for repair-provided of course that the bailee is a merchant who deals in goods of that kind. ${ }^{149}$

This is a major departure from the position under the Factors Act, involving as it does the concept of the "commerciality" of the goods as opposed to the "purpose of the bailment" test under the Factors Act. ${ }^{14}$ Under $\mathrm{s}$. 5 of the New South Wales Act the mercantile agent must be entrusted "as such" with possession, "1." and it has generally been accepted that he must be entrusted with possession for the purpose of sale, and that if he took possession for instance as a hirer under a hire-purchase agreement, even for the purpose of sale, he was a bailee and was not entrusted with possession as a mercantile agent. As against this view, there is the opinion of Denning, L.J., in Pearson v. Rose and Young Ltd.140 that it is sufficient if the agent has possession for a purpose which is in some way or other connected with his business as a mercantile agent, such as for display or to attract offers to buy. Such a view would prevent the unduly restrictive interpretation that appears to have been applied in such cases as Universal Guarantee Pty. Ltd. v. Metters Ltd. ${ }^{1+i}$ and would be more consonant with justice. A policy decision has to be made whether to go the whole of the way that the Code has gone and allow a bona fide purchaser to acquire a good title where he has acquired the goods from a dealer, or whether attention should still be paid to the purpose for which the bailment was made, while at the same time liberalizing the strict approach which has been adopted in the past. In this connection, the recommendations of the English Law Reform Committee in its Twelfth Report already referred to ${ }^{1 *}$ are worthy of mention as indicative of the lengths towards establishing the "commerciality" of goods that it was prepared to go.

As mentioned earlier in this paper, the majority of the Committee favoured enactment of legislation which would enable a person who bought goods in good faith and without notice of any defect in title by retail at trade premises or at a public auction to acquire a good title thereto. The onus of proof of his bona fides would rest on the purchaser who was not to acquire a good title "if he had actual knowledge of any facts or circumstances which should have led him to infer the existence of some defect of title or to make enquiries which would have revealed the existence of such a defect." Trade premises were defined as premises open to the public at which goods of the same or a similar

14: Another clause in the same section-s. 2-403(1)(d)-renaers immaterial the distinction between larceny and false pretences for the purposes of sale of goods by stipulating that a good title can be transferred even thougli the seller procured the goods through fraud punishable as larcenous. This accords with the cominon law positionSee Du Jardin v. Beadman Bros. Ltd.. [1952] 2 Q.B. 712.

143 In Adkins v. Damron (1959). 324 S.W. 2d. 489. 491 the Kentucky Court of Appeal sugsested that an article returned to a seller for repaix and fraudently resold by him might be lost to the owner under s. $2-403$ of the U.C.C.

its It is also a major departure from the position under the U.S.A. Indeed. Cillifornia was sufficiently apprehensive of the chanse to restrict the definition of "entrusting" to delivery, etc., for the purpuses of sale, obtaining offers to purchase. locating a buyer, or the like.

14i. The wording differs in other State Acts but the effect is probably the same. See Cook v. Rodgers, supra. n. 124, at 232. The writer cannot stress too strongly the desirability of uniform legislation in this field.

14 i $[1951 \mid 1$ K.B. 275, 288.

14: $1966 \mid$ W.A.R. 74 F.C.

148 Transfer of Title of Chattels, supra, n. 20. 
description to those sold were normally offered for sale by retail in the course of business carried on at those premises.

This proposal was made with reference to a suggestion for the reform of the law as to sales in market overt, and while it was obviously intended to encompass the sale of stolen goods, it would also seem to have much wider implications than that. The Report appears to regard any unauthorized disposal of goods by a trader as within the scope of the proposal. Thus, if goods are entrusted to a mercantile agent for storage or repair, any disposal of these to an innocent third party will be valid as against the owner, and questions of whether the agent acted in the ordinary course of business or whether he was in possession as a mercantile agent will be irrelevant.

If an innocent purchaser is to obtain a good title to stolen goods where he buys them at trade premises, it is logical to allow him to obtain a good title in similar circumstances where the owner has made the initial move by entrusting the goods to the trader even though it be for purposes other than sale. The competing interests of owner and buyer are resolved in favour of the buyer in good faith from the merchant. The Committee's proposals, as with the provisions of the U.C.C., ${ }^{160}$ mark the triumph of the view that possession is nine-tenths of the law and that the bona fide purchaser is to be protected, not because of his praiseworthy character (after all, he might have been careless), but because modern business conditions demand that commercial transactions should be concluded without elaborate investigations of proprietary rights and in reliance on the possession of goods. A notable precedent for this view is to be found in S. 27 Hire-Purchase Act 1964 (U.K.) which allows a private purchaser of a motor vehicle, the subject of a hire-purchase agreement or instalment contract of sale, to obtain a good title if he acts in good faith and without notice of the agreement.

The writer's personal view is that an owner should be able to store his goods or leave them for repair with a merchant without having to bear the risk of loss through fraudulent disposal of them to an innocent third party. In other words, it is suggested that the common-law doctrine, whereby an owner who entrusted goods for sale to a merchant took the risk of their wrongful disposal in the ordinary course of business, should not be broadened to the extent that any delivery of chattels to the merchant is enough, but should be widened only to this extent, that the owner loses his rights where entrusting (be it on "hire" or under a "floor plan" arrangement or similar scheme or merely a bailment) is for some purpose connected with sale, such as soliciting offers to buy or to take on hire purchase, and the like. Entrusting for sale should not be narrowly interpreted, but the entrusting should be something more than the mere handing over of goods for purposes of storage or repair. This view is, no doubt, illogical but it represents a compromise in resolving the competing claims of owner and bona fide purchaser, rather than adopting the view of the Code that the buyer is to be protected at the expense of the owner whenever goods are sold in an unquestionably commercial setting. A fortiori, the owner of stolen goods should be able

149 The U.C.C. is narrower than the Committee's proposals in that the owner can recover stolen goods from a bona fide purchaser under the Code. i.e. the owner must voluntarily part with them for s, $2-403(2)$ to apply. 
to get his goods back unless he has been careless. The doctrine of caveat emptor should still have some meaning.

The U.C.C. stipulates that the purchaser must be a "buyer in ordinary course of business", not that the merchant should act in the ordinary course of business in disposing of the goods. This may be more restrictive than the bona fide purchaser for value of the S.G.A. and the Factors Act, ${ }^{1 ; 0}$ but it does pay attention to the circumstances and knowledge of the buyer at the time of the transaction rather than to the circumstances under which the merchant obtained possession, and would thus avoid the difficulties that arose in such cases as Pearson v. Rose \& Young Ltd. ${ }^{131}$ and Stadium Finance Ltd. v. Robbins" ${ }^{152}$ (where the "logbooks" of certain motor vehicles were improperly obtained by the dealer and the sale by him was held to be outside the ordinary course of business.) All that is required of the buyer is that the transaction must be apparently regular on its face.

If the provisions of the Factors Act are to be widened in the manner suggested, some modifications will have to be made to s. 28 S.G.A. which was originally to be found in the Factors Act 1877 (U.K.). Indeed the most appropriate course to take would be to incorporate the provisions of the Factors Act in the S.G.A. and to present the law on this topic as a whole, alongside $s$. 28, suitably amended in the light of the decisions. Under s. 28, a buyer or seller in possession of goods can pass a good title to an innocent third-party in certain circumstances. ${ }^{153}$ The terms of s. 28 (2) should be amenaed so as to correspond with those of $s$. 28(1) so far as the effect of any disposition is concerned, and in fact the simplest solution would be to provide in both cases that the innocent sub-purchaser obtains a good title. Further, if under s. 28(1) the vital feature is that the seller should be in continuous possession, and it is immaterial whether the character of that possession should have changed to that of a hirer or otherwise, ${ }^{1: 4}$ and if a mercantile agent will be able to pass a good title where he holds the goods on hire so as to attract offers to buy, should not a "buyer" who holds goods on hire-purchase be able to pass a good title to an innocent third party under s. 28(2) ? The result no doubt would be to abolish the vital technical distinction between hire-purchase and sale which was established in Helby v. Matthews, ${ }^{15 \pi}$ but this is what has in effect been done in relation to the disposal of motor vehicles at least to private purchasers by s. 27 HirePurchase Act 1964 (U.K.). It should be recognized that the hire-purchase transaction is in effect a sale, and that the owner of hired goods should not be entitled to any greater protection than a seller can obtain under an outright sale. ${ }^{150}$

1.i1) See the definition in S. 1-201 (9) U.C.C.

j:1 Supra, n. 146.

15: [1962] 2 Q.B. 664.

1:3 A buyer was never given such power under the U.S.A., while under the U.C.C. a seller in possession must be a merchant who deals in goods of that kind to enable him to pass title to a buyer in ordinary course. In other words, the "negotiability" of goods is restricted to their disposal in a commercial setting.

$15 t$ See Pacific Motor Auctions Pty. Ltd. v. Motor Credits (Hire Finance) Ltd., [1965] A.C. 867.

$10.3[1895]$ A.C. 471.

130 It has been said that hire-purchase transactlons in all but motor vehicles has declined in N.S.W. by $61 \%$ in the last nine years in favor of credit facilities offered by retallers or the negotiation of bank loans to cnable purchase at a discount for cash. This reveals a swing by traders awoy from the right to repossess goods on default (an advantage that may be more theoretical than real in view of the statutory restrictions on re-possession) in favor of the assessment of the credit rating of the potential buyer and the ability to enforce payment of the price. State-imposed stamp duties on hire-purchase agreements have also contributed to the decline. See the "Sunday 
It seems appropriate to conclude on this iconoclastic note. It is clear that the reform of the law of sales, if it is to be done adequately, will be no light task, and it is hoped that the suggestions contained in the foregoing pages will engender interest in the modernization of this area of the law and provide a point of departure for discussion and argument leading up to the formulation of sales legislation which will be in keeping with the times. If it achieves that much, this paper will have been well worth while.

One final word can be spared for the ultimate consumer, a category into which all of us come at one time or another. No matter how farreaching any reform of the law of sales or how widespread the consumer's civtl remedies are made to appear, these remedies are of practical value only where the price of the product warrants the expense of bringing proceedings. The cost of litigation is a serious deterrent of which unscupulous manufacturers or retailers are not slow to take advantage, and in these circumstances it is small comfort to the purchaser to know that the courts of justice, like the Chevron Hotel, are open to all. Some thought should be given to invoking the criminal law so that the manufacturer or retailer would be open to prosecution for committing an offence and at the same time empowering the Court to order payment of compensation to the consumer. The alternative is to establish a cheap method of enforcing the consumer's rights along the lines, say, of the Small Debts Court of New South Wales and to take the risk that this course of action may breed a race of Albert Haddocks. ${ }^{27 *}$

Telegraph" of 10th March, 1968. If this attitude to repossession continues, there will no longer be any valid reason for perpetuating the distinction between hire-purchase and sales.

10: See Sir Alan Herbert, Uncommon Law.

Author's note: Since this article was written The Trade Descriptions Act No. 2 (U.K.) has come into force. greatly extending criminal liability in respect of mis-description of goods. Also The United Kingdom Law Comnission, Working Paper No. 18, contains provisional proposals for ammendments to ss. 12-15. Sale of Goods Act 1897 (U.K.), l.e., the implied conaitions and warranties sections. 